\title{
NEW MEDIA IN IMAGE-MAKING. HOW HAVE EMERGING COMMUNICATIONS TRANSFORMED THE POLITICAL PROCESS?
}

\author{
ARTUR URBANIAK \\ A change in the type of medium implies a change in the type of appraisal \\ and hence makes it difficult for one civilization to understand another.
}

Harold Innis

\begin{abstract}
The purpose of this article is to provide a theoretical framework for the contemporary process of political communication. It emphasizes the changing roles of the senders/receivers within the process and it postulates unprecedented opportunities offered by the emergence of the New Media. As for the empirical research, we discuss the results of the study that has been conducted to further the understanding of how the younger generation, aged 20-25 (herein referred to as Digital Natives), process and comprehend the news media content, with special attention to political messages. It was initially hypothesized that the main source of information about politics and the surrounding world is the Internet and the social media in particular. The paper discusses the results of the study showing that the alternative news websites and social media, understood as the opposite to what is known as the mainstream media, have been gaining ground. Concurrently, the study discovered the students' declining interest in traditional institutional mainstream-controlled media (i.e. press, radio or television).
\end{abstract}

Key words: political communication, new media, Digital Natives, image making, political representations

\section{Image-making in contemporary politics}

Political Communication is an intricate and interrelated two-way process intended at exchanging information between political actors (herein defined as politicians) and the citizens/voters (cf. Dobek-Ostrowska, 2006; Skwark, 2012; Urbaniak, 2014). 
The technological advance and the emergence of New Media has significantly transformed the process of political communication. However, it is not only the channel of communication that has been reshaped. It is rather the philosophy underlying the concept of political communication.

The rise of citizen journalism gives the public an opportunity for producing news which has been previously controlled by mass media institutions. In this case, the citizen acts not only [as] a news consumer, but also as a news producer and consumer at the same time [...] (Nasrullah, 2014: 3).

Declining interest in traditional media represented by TV, radio and press has been observed through numerous studies and research conducted all over the globe, both scientific and commercial (Conover et al., 2011; Himelboim et al., 2012; IS 1; IS2; IS3). Poggi, in her article on media preferences among "Gen Exers", argues that "[a]lmost half of adults 22 to 45 years old are watching absolutely no content on traditional TV platforms" (IS 2). It does not mean, however, they are not consuming TV content at all. It is rather to emphasize that the public switched to new streaming platforms, the ones that did not exist before, which makes them "unreachable" by marketers (ibidem). Analyzing extensive research materials available and frequently published by specialized media agencies and global marketing research firms (such as Nielsen Corporation), it might be concluded that the younger the person, the less traditional TV content they consume (for a detailed analysis see IS 3). This exemplifies how the emergence of the New Media on the market has transformed the process of spreading information. We observe the change of habits in Millennial Generation and Digital Natives (the terms after Howe and Straus, 1991 and Prensky, 2001, respectively) from mere consuming the mass media content offered by institutional media towards more active participation or, at least more conscious choices being made, through resorting to non-commercialized alternative media.

In view of politics and sending political messages, what actually revolutionized the whole process is the non-existence of gatekeepers (acting as access controllers). Taking into account the mechanisms characteristic of Agenda Setting (McCombs and Shaw, 1972), traditional news media institutions could influence the importance of topics presented in the public agenda. This way the governments or media owners were able to regulate (or manipulate) the news content, directing people's attention towards certain topics and diverting their attention from others (Lewin, 1943; Hacker, 2008). With the emergence of the New Media available online, it is more difficult to influence audiences because of greater pluralism of media sources and a greater scope of satisfying individual preferences. In western liberal democracies, being granted access to numerous news sources all across the globe, the public can decide

\footnotetext{
${ }^{1}$ Generation X, the demographic cohort following baby boomers, born from 1960s to 1980s, which in this paper is referred to as the generation preceding the Digital Natives.
} 
which websites they wish to visit, and which news feeds they trust. Visiting numerous news websites, the public can also compare the news coverage presented and draw conclusions for themselves, and therefore, the predominant position of gatekeepers and opinion leaders is put into question. What we are experiencing now can be referred to as Agenda Melding, i.e. "the process by which audience members seek out and blend media agendas from various communication sources to fit their individual preferences and cognitions" (Shaw and Colistra, 2008: 11).

Normahfuzah (2017: 71) states that "[t]echnological advances in any given era shape their historical moment and affect the public they serve". In view of political communication, the real highlight of the day seems to be the digital media, the alternative media and the social media in particular. The choice of the right channel of communication, the one enabling the sender/political actor to reach mass audiences, might exercise considerable influence on the intended success of the message. In this case, the success is directly connected with the sender's popularity. For a politician, anonymity means non-existence. Without being widely recognized, the political activists simply sink into oblivion. No matter how sagacious, experienced or knowledgeable political actors are, first and foremost, they seek to be recognizable, and new media seem to be the means of getting the much-desired recognition. DobekOstrowska (2006: 273) defines it in terms of media visibility (Polish widoczność medialna): flooding the public with information about political actors by mass media. Presently, with relatively low numbers of young people reaching for press or watching news on TV, political actors learned how to come into the being in the realm of cyberspace.

Lippmann (1922) argued that people do not engage in political affairs directly. Instead, they respond to representations of politics produced by opinion leaders, journalists and PR specialists. Political messages influence people's behavior indirectly by affecting perceptions. The perception of political messages is conceptually related to the images created in people's heads. That is how the social sciences emerged with the concept of Political Image, briefly defined as "cognitive representations of political subjects" (Hacker, 2008: 322). Innis (1950/2007: 26-27) put emphasis on the role of the media in the world's development, writing:

The concepts of time and space reflect the significance of media to civilization. Media that emphasize time are those that are durable in character, such as parchment, clay, and stone. The heavy materials are suited to the development of architecture and sculpture. Media that emphasize space are apt to be less durable and light in character, such as papyrus and paper. The latter are suited to wide areas in administration and trade.

Presently, instead of parchment or stone, press or television, political actors turned to digital media which offer a plenitude of unprecedented opportunities for making fast and direct contact with mass audiences. The concept of Web 2.0, i.e. the New Media, offers one feature that makes it significantly different from all previous- 
ly known media - interactivity (Salcedo-Maldonado, 2012). Theoretically, Web 2.0 together with its potential should be seen as another milestone in the development of the media and political communication itself. The remaining question, however, is whether the intended target group of the New Media, named Digital Natives, whose preferences will be discussed further on in this paper, actually manifest any sign of being ready (maturity) to involve in the ongoing process of exchanging information.

\section{Digital Natives, new media and alternative media}

In order to avoid conceptual inaccuracy, let us concisely define the demographic cohorts presented herein. The term Millennials is used with regard to people born between 1982-2000 (Howe and Strauss, 1991). The concept of Net Generation (Tapscott, 1998) was created with a close consideration of social and business impact made by a digital generation i.e. the people who grew up surrounded by digital media. This one can be used interchangeably with another term, coined by Prensky (2001) and used mainly in pedagogy, Digital Natives, also referring to those who were growing up with technology around (cf. Urbaniak, 2016a). Prensky (2001) argues that today's students process information differently from the previous generations because their brains have actually changed as a result of the new conditions in which they were brought up. In contrast to Digital Natives, Digital Immigrants are the generation in whose lifetime the Internet first came into being and who had to learn how to use technology.

Confronted with several terminological ambiguities, let us briefly discuss the key concepts connecting political communication with the contemporary media: (1) New Media, (2) Social Media and (3) Alternative Media. Dimitrova (2008: 490) observes: "[w]hile there is no universally accepted definition of new media technologies, they can be best understood as new forms of media technology or new applications of existing media technology". The Internet offers multiple information and communication technologies - herein referred to as New Media as opposite to Traditional Media (press, radio and television) - which can benefit to spreading information in a fast and uncontrolled manner. Blogging, micro-blogging (Twitter), online video sharing (YouTube) and social media (Facebook, LinkedIn) are widely used in political communication to share or popularize the political content (Salcedo-Maldonado, 2012; Wojcieszak and Smith, 2013; Bonilla and Rosa, 2015). But it is the type of participation and the level of interactivity that really matters. And interactivity is an inherent feature of social media. It is reported that Facebook, Twitter, and YouTube are used for political communication and social mobilization in such political events as the collective movements termed the "Arab Spring" that followed the popular uprising in Iran in 2009 (see Wojcieszak and Smith, 2013), in 
presidential campaigns in the U.S. (Berbera et al., 2015) or in spreading fake news or downgrading political opponents (Urbaniak and Buczowski, 2018).

The New Media enable users to become actively involved in the process of political communication. Taking into account the level of engagement, we can divide users into seven categories described below:

1) creators make the actual content consumed by other members of the digital society, through uploading videos, texts, pictures, writing blogs or placing short comments on micro-blogs,

2) conversationalists share their opinions with consumers using social media, bringing others into discussion,

3) critics limit their activity to responding to other users' posts, reviewing and commenting on them,

4) collectors find and organize the content for others; they also distribute the news and spread ideas that might potentially interest their followers/friends,

5) joiners create profiles on social networking sites and follow, and in a way, contribute to the redistribution of the news content,

6) spectators limit their activity to consuming the content placed by other users,

7) inactives do not engage in the process, refraining from creating or consuming the content (after Croteau and Hoynes, 2014: 297-8).

Social media are used "to turn communication into an interactive dialogue" (Salcedo-Maldonado, 2012: 5). They enable political actors to build public or semi-public profiles which allow them to share the series of connections (friendships, interests), and this way, to reach wide audiences with their messages. It seems a large-scale, fast and low-cost solution. Presently, the social media are among the fastest growing services on the Internet (ibidem), offering unprecedented opportunities for political actors to create the desired political images described earlier in this paper.

Alternative Media show us not only how technology transforms the pattern of information consumption from traditional media, but also how the Internet might influence the mechanism of news production as well as the distribution and consumption of information (Nasrullah, 2014; Urbaniak, 2016b). Herein, we define the Alternative Media as:

a form of mass media that has arisen as a contrast to mainstream media. Mainstream media is mass media (newspapers, radio, television, magazines, movies, Internet, etc.) that disseminate information that is inline with the thoughts, interests and opinions of the current general society. Alternative media thus becomes those mass media outlets that disseminate information that is in contrast to the thoughts, interests and opinions of the current general society (IS4).

Seeking alternative sources of information might be read as an expression of disapproval or discontent of mainstream media messages. The experiment whose results are discussed in the following section is to shed more light on the profile of 
the contemporary media user, aged 20-25. On the assumption that Digital Natives are offered a powerful tool for making real impact on the surrounding reality, just through posting comments, asking questions and being able to contact decisionmakers directly, it needs to be clarified whether they make use of this tool.

\section{The experiment}

This section discusses the aims as well as the course of the study, followed by the presentation of the results. Joining in a heated debate on the political engagement of contemporary youths, the author decided to validate whether the representative sample of educated young Polish citizens, being offered numerous opportunities to have their say via new media, actively involves in political processes. In a pilot study conducted on a sample of 80 students $(n=80)$ from Poznan University of Technology in May and June 2017, a pollster articulated four questions, concerning the students' declared civic engagement made available through digital media. The results of the examination, namely the aforementioned four questions followed by the commentary are presented in the following subsections.

\subsection{Test group}

The research was conducted on a heterogeneous group of 80 students from the Faculty of Computing and the Faculty of Electrical Engineering at Poznan University of Technology. The test group consisted of 68 males and 12 females. The predominance of men seems typical of the faculties where the study was conducted. The median age for the test group was 20 years old, while the age of the participants spanned from 19 to 25 . The group selected for the experiment was somewhat privileged in terms of computer use, because it consisted of technically apt and computer literate IT students. The participants were proficient at social media use and did not find it difficult to enter the realm of cyberspace.

\subsection{The study procedure}

Each of the respondents was handed over a questionnaire containing four questions and their task was to choose one answer which best suits or reflects their opinion(s). The first question was related to exercising civic duties and it read: (1) How would you describe the level of your political engagement. The respondents could choose among five options presented in Table 1. It can be easily inferred from the data gathered that the majority of those questioned declared to be either mildly engaged $(\mathrm{n}=43)$ or rather involved $(\mathrm{n}=31)$ in politics. 
Table 1. Civic engagement in politics

\begin{tabular}{|l|c|}
\hline \multicolumn{1}{|c|}{ Declared level of engagement } & Number of respondents $(\mathbf{n}=\mathbf{8 0})$ \\
\hline Deeply engaged & 2 \\
\hline Rather involved & 31 \\
\hline Mildly engaged & 43 \\
\hline Not engaged & 3 \\
\hline None of the above & 0 \\
\hline
\end{tabular}

As for the second question, those polled were asked to point to the main source of news about politics, namely the one they collect the information from most frequently. This time the respondents were offered six alternatives to choose from: a) traditional press (meaning e.g. daily newspapers or weekly magazines), b) mainstream Internet portals (through which we meant the ones generally accepted by the public, the kind of media-source connected with the biggest media institutions), c) online alternative media (portals which are crowd-funded or supported by their followers or other non-official news sources including private blogs or YouTube channels run by individuals, etc.), d) television, e) radio (including both commercial and non-commercial broadcasters) as well as f) other sources (to be named). Formulating the question this way enabled us to verify whether the respondents only changed the mere medium (i.e. traditional newspapers and Television broadcasts were replaced with online news sources controlled by the same media institutions) or whether they actually changed the sender/broadcasting station (mainstream media were replaced with alternative media).

Table 2. Prevailing Media Attitudes

\begin{tabular}{|l|c|}
\hline \multicolumn{1}{|c|}{ Media Source } & Number of respondents (n=80) \\
\hline Traditional press & 0 \\
\hline Mainstream Internet portals & 11 \\
\hline Internet alternative news media & 43 \\
\hline TV & 15 \\
\hline Radio & 3 \\
\hline Other & 4 \\
\hline
\end{tabular}

Apparently the most popular news source in a tested group were alternative online sources, covering more than $50 \%$ of the responses $(n=43)$. The second popular was television with 15 people out of 80 treating this medium as trustworthy, which constitutes barely $12 \%$ of the total number of responses. Mainstream news portals available online seem to be a trustworthy source of information about politics 
only for 11 respondents (less than 9\%). Additionally, it is worth pointing here that no one claimed to reach for traditional press any more.

The third question concerned engagement in a political debate through leaving comments and opinions as well as joining in discussions on social media. Although the respondents earlier declared to be either mildly $(n=43)$ or rather engaged $(n=31)$ in political matters, this assumption does not find confirmation in their active involvement in online discussions. The participants were asked to indicate how often they leave comments, opinions or join in the online political discussions or debates through making remarks on forums available under news contents, usually at the bottom of the websites. Table 3 below presents the responses.

Table 3. Online activity

\begin{tabular}{|l|c|}
\hline \multicolumn{1}{|c|}{ Frequency } & Number of respondents $(\mathbf{n}=\mathbf{8 0})$ \\
\hline Very often & 4 \\
\hline Occasionally & 6 \\
\hline Seldom & 32 \\
\hline Never & 38 \\
\hline
\end{tabular}

The majority of the respondents never trouble to leave comments or have their say $(n=38)$. Consuming the media content seems far more popular than engaging in conversations, with 32 respondents claiming to participate in online discussions very seldom and only 4 people declaring to actively involve in the exchange of opinions on regular basis (very often). And slightly more, 6 respondents, occasionally posting comments.

The fourth question was aimed at validating the type of the respondents' occasional engagements into online political debates. They were offered seven types of engagement as described in Section 2 of the paper, namely: creator, conversationalist, critic, collector, joiner, spectator and inactive. Their task was to choose one type of engagement that they believe to represent.

Table 4. Types of online political engagement

\begin{tabular}{|l|c|}
\hline \multicolumn{1}{|c|}{ Declared type of engagement } & Number of respondents $(\mathbf{n}=\mathbf{8 0})$ \\
\hline Creator & 4 \\
\hline Conversationalist & 3 \\
\hline Critic & 8 \\
\hline Collector & 15 \\
\hline Joiner & 16 \\
\hline Spectator & 32 \\
\hline Inactive & 2 \\
\hline
\end{tabular}


As for the results, 32 respondents regarded themselves as spectators, while 16 saw themselves as joiners and 15 as collectors. Only 4 people claimed that they were creators of the content, and even fewer (3) stated that they engaged in online conversations. Two people declared to be inactive.

\subsection{Discussion of research findings}

It seems that several conclusions can be drawn after a deepened analysis of the results of the experiment. Apparently most relevant is the fact that leaving behind the Traditional Media, the respondents indicated that they also left behind the mainstream media. The emergence of new channels of communication enabled the public to search for alternative sources of information. The news sources which are not legitimized by the establishment, which might potentially have the biggest effect on democracies all across the globe, and which might actually revolutionize the way young people make their choices in connection with political elections.

The study confirms that, all in all, young people, aged 20-25, are not too concerned with politics. Although they declared to be either "mildly engaged" or "rather involved" in the process of political communication. It seems that it all ends with declarations. A relatively small portion of the respondents declare to take active part in political processes through such actions as creating content, posting comments, polemics or rational critique. More often they find themselves comfortable in a role of a passive observer (spectator) or a joiner / collector. However, there is one significant difference between being a passive consumer of the traditional mainstream media and being a spectator in the process of political communication online in the social media. The latter do not "consume" all the content they are being flooded with by media institutions; on the contrary, they carefully limit and select the content and - probably - give it a second thought. Their opinions are formed on the basis of the content they have selected or they have been presented by the people they trust. Most probably, as for the media institutions, there is no getting back to what it used to be like. Turning to alternative media, young people expressed both distrust and discontent to the institution of media as the trustworthy sources of information, and therefore questioning the media veracity.

\section{Concluding remarks}

The New Media, as defined in the paper, offer unprecedented possibilities to both message senders (the politicians), and message receivers (the public); this new element is interactivity. Now, the receivers might at the same time become senders of the political messages. They were given a powerful tool thanks to which they can 
actually create or reshape the reality. It might be achieved with relatively low effort, through such actions as posting comments, asking questions, direct polemic with political actors or simply by popularizing (sharing or retweeting) information. For a member of the cybersociety, there is no need for leaving home or taking part in political demonstrations in order to be heard. It is enough to turn on a computer and express their thoughts in social media to make a change. Presently, all media consumers are offered an alternative to the old traditional, institutional, mainstreamcontrolled messages. It is only a matter of choice what media content a person trusts. A classic propaganda model was a one-way model of communication, while what people are offered now is a fully-interactive, instant, low cost solution, referred herein as New Media, which transformed political communication into a two-way process of communication. However, what might be inferred from the study presented in the paper, young people seem not to be ready for this revolutionary change. Whether they do not fully understand the potential the Internet gives or they do not feel the need to become more actively engaged in political processes remains unclear and leaves room for further studies.

\section{References}

Bielak, M. I. and J. Taborek (eds.). 2016. A dialogic contribution to determinants of glottodidactic space. Piła: Stanisław Staszic University of Applied Sciences.

Bonilla, Y. and J. Rosa. 2015. ,\#Ferguson: digital protest, hashtag ethnography, and the racial politics of social media in the United States". American Ethnologist 42 (1). 4-17.

Barberá, P., J. T. Jost, J. Nagler, J. A. Tucker and Richard Bonneau. 2015. "Tweeting from left to right: is online political communication more than an echo chamber?". Psychological Science 26 (10). 1531-1542.

Conover, M. D., Ratkiewicz, J., Francisco, M., Goncalves, B., Flammini, A. and F. Menczer. 2011. Political polarization on Twitter. Proceedings of the Fifth International AAAI Conference on Weblogs and Social Media, Barcelona, Spain, July 17-21, 2011. Retrieved from: https://www.aaai. org/ocs/index.php/ICWSM/ICWSM11/paper/view/2847 [last access: 1.08.2018].

Croteau, D. and W. Hoynes. 2014. Media/Society. Industries, images, and audiences. Los Angeles: Sage Publications.

Dimitrova, D.V. 2008. "New Media technologies". In: Kaid L.L. and Ch. Holtz-Bacha. (eds.). Encyclopedia of political communication. London: Sage Publications. 489-493.

Dobek-Ostrowska, B. 2006. Komunikowanie polityczne i publiczne. Warszawa: Wydawnictwo Naukowe PWN.

Gibson, R. 2013. "Party change, social media and the rise of 'Citizen-initiated' Campaigning". Party Politics 21 (2). 183-197.

Hacker, H. 2008. "Political image". In: Kaid, L.L. and Ch. Holtz-Bacha. (eds.). Encyclopedia of political communication. London: Sage Publications. 322-325.

Himelboim, I., Ruthann Weaver L., Tinkham, S.F. and K.D. Sweetser. 2012. "Social media and online political communication: the role of interpersonal informational trust and openness". Journal of Broadcasting and Electronic Media 56 (1). 92-115. 
Howe, N. and W. Strauss. 1991. Generations: the history of America's future. New York: Quill.

Kaid, L.L. and Ch. Holtz-Bacha. (eds.). 2008. Encyclopedia of political communication Vol. 1 and 2. London: Sage Publications.

Kaufmann, M. and J. Jeandesboz. 2017. "Politics and 'the digital': from singularity to specificity". European Journal of Social Theory 20 (3). 309-328.

Kreiss, D. 2012. Taking our country back: the crafting of networked politics from Howard Dean to Barack Obama. New York: Oxford University Press.

Kulczycki, E. and M. Wendland. (eds.). 2012. Komunikologia. Teoria i praktyka komunikacji. Poznań: Wydawnictwo Naukowe Instytutu Filozofii UAM.

Lasorsa, D.L. 2008. “Agenda setting”. In: Kaid L.L. and Ch. Holtz-Bacha. (eds.). Encyclopedia of political communication. London: Sage Publications. 12-19.

Lippmann, W. 1922. Public opinion. New York: Harcourt Brace.

Lewin, K. 1943. "Psychology and the process of group living". The Journal of Social Psychology 17. 113-131.

Nasrullah, R. 2014. “'Selling' self-image in the era of new media”. Humaniora 26 (1). 3-12.

Normahfuzah, A. 2017. "The decline of conventional news media and challenges of immersing in new technology”. eSharp 25 (1). 71-82.

Nulty, P., Theocharis, Y., Popa, S.A., Parnet, O. and K. Benoit. 2016. "Social media and political communication in the 2014 elections to the European Parliament". Electoral Studies 44. 429-444.

Manovich, L. 2003. "New media from Borges to HTML.” In: Wardrip-Fruin, N. and N. Montfort. (eds.). The new media reader. Cambridge, Mass.: The MIT Press. 13-25.

McCombs, M. E. and D. L. Shaw. 1972. "The agenda setting function of mass media". Public Opinion Quarterly 36. 176-187.

Prensky, M. 2001. "Digital Natives, Digital Immigrants". On the Horizon 9 (5). 1-6.

Puppel, S. (ed.). 2017. Scripta Neophilologica Posnaniensia XVII. Poznań: Katedra Ekokomunikacji UAM.

Puppel, S. 2011. "An outline of a multiply triune continuum model of language and communication". Oikeios Logos 8. 1-25.

Puppel, S. and J. Puppel. 2008. "Gestosfera jako istotny składnik przestrzeni publicznej: wstępny zarys problematyki”. Oikeios Logos 4. 1-8.

Puppel, S. 2004. "An outline of a domain-resource-agent-access-management (DRAAM) model of human communication: towards an ecology of human communication". Oikeios Logos 1. 1-26.

Salcedo-Maldonado, J.S. 2012. Making ideas spread. Brussels: Centre Maurice Coppieters.

Shaw, D.I. and R.F. Colistra. 2008. "Agenda melding". In: Kaid L.L. and Ch. Holtz-Bacha. (eds.). Encyclopedia of political communication. London: Sage Publications. 11-12.

Skwark, S. 2012. "The medium is the message. O sieci, komunikowaniu politycznym i social media". In: Kulczycki, E. i M. Wendland. (eds.). Komunikologia. Teoria i praktyka komunikacji. Poznań: Wydawnictwo Naukowe Instytutu Filozofii UAM. 111-126.

Tapscott, D. 1998. Growing up digital: the rise of the Net generation. New York: McGraw-Hill.

Urbaniak, A. and Buczowski M. 2018. Czy nadchodzi era politycznych celebrytów?. In: Wiertlewska, J. (red.). Język - dydaktyka - komunikacja. Toruń: Wydawnictwo Naukowe Uniwersytetu Mikołaja Kopernika. 153-178.

Urbaniak, A. 2017. "Larva, pupa, imago: próba redefinicji pojęcia wizerunku politycznego w ujęciu komunikologicznym". Scripta Neophilologica Posnaniensia XVII. 365-376.

Urbaniak, A. 2016(a). "Developing communicative competence in digital natives. A weblog as a tool for teaching writing skills in tertiary education". In: Bielak, M.I. and J. Taborek. (eds.). 141-154.

Urbaniak, A. 2016(b). "Kompetencje komunikacyjne: Czy polska scena polityczna jest gotowa na swojego Jesse ‘the Body' Venturę?”. The Journal of Linguistic and Intercultural Education 9 (2). 189-201. 
Urbaniak, A. 2014. Rola elementów werbalnych i niewerbalnych w komunikacji politycznej końca XX i początku XXI wieku na podstawie wybranych wystapień medialnych polskich polityków. Poznań: Katedra Ekokomunikacji UAM.

Wiertlewska, J. (ed.). 2018. Język - dydaktyka - komunikacja. Toruń: Wydawnictwo Naukowe Uniwersytetu Mikołaja Kopernika.

Wojcieszak, M. and B. Smith. 2013. "Will politics be tweeted? New Media use by Iranian youth in 2011". Iran Media Program. Retrieved from: http://repository.upenn.edu/iranmediaprogram/1 [last access: 2.08.2018].

\section{Internet Sources}

IS 1: "Social and mobile up, TV down: GroupM". Retrieved from: http://mediaincanada.com/2018/ 06/20/canadians-are-pulling-the-plug-on-tv-groupm/ [last access: 1.08.2018].

IS 2: Poggy, J. "Nearly half of Millennials and Gen Xers don't watch any traditional TV: study". Retrieved from: http://adage.com/article/media/half-young-consumers-watching-content-traditional-tvstudy/310564/ [last access: 1.08.2018].

IS 3: The state of traditional TV: updated with Q2 2017 Data. Retrieved from: https://www.market ingcharts.com/featured-24817 [last access: 1.08.2018].

IS 4: Alternative media, posted in marketing and strategy terms. Retrieved from: https://www.mbaskool.com /business-concepts/marketing-and-strategy-terms/14014-alternative-media.html [last access: 27.07.2018]. 